\title{
Notes
}

\section{The Supreme Court and "Civil Rights,"}

\section{6-1908}

\section{David Bernstein}

In the United States, the term "civil rights" originally referred to people's "natural rights" to life, liberty, and property as protected by civil law. ${ }^{1}$ Many civil rights advocates believed that individuals had not only the right to equal protection of the laws ("equal rights"), ${ }^{2}$ but also to "economic liberty." 3 Economic liberty included the right to own and alienate property and the right to contract freely and to have the government enforce those contracts ("freedom of contract"). Because slavery was the dominant civil rights issue of the nineteenth century, a subsidiary of freedom of contract, the right to pursue a lawful profession and to alienate one's labor in a free market ("occupational liberty") became an inviolable part of the Republican civil rights ideology ${ }^{4}$ and the most prominent issue on the post-Civil War national civil rights agenda. ${ }^{5}$

1. See C. Bolick, Changing Course: Civil Rights at the Crossroads 3-11 (1988)

2. Throughout this Note, the phrase "equal rights" is used in its classical liberal sense, i.e., the right to be free from discrimination by the government.

3. C. BoLICK, supra note 1; Hovenkamp, The Political Economy of Substantive Due Process, 40 STAN. L. REV. 379, 395 (1988).

4. See Maltz, Reconstruction Without Revolution: Republican Civil Rights Theory in the Era of the Fourteenth Amendment, 24 Hous. L. REV. 221, 225 (1987) ("It was the . . . concept of natural rights which was the foundation of the consensus Republican conception of the rights to which blacks were necessarily entitled. Perhaps foremost in the anti-slavery pantheon was the right to freely buy and sell one's labor.").

5. The Civil Rights Act of 1866, ch. 31, 14 Stat. 27 (1866), which most scholars agree was constitutionalized by the Fourteenth Amendment, focused on economic liberty. See Note, Resurrecting Economic Rights: The Doctrine of Economic Due Process Reconsidered, 103 HARV. L. REV. 1363, 1369 (1990). 
In the 1886 case Yick Wo v. Hopkins, ${ }^{6}$ the United States Supreme Court embraced the prevailing civil rights philosophy. Relying on both equal rights and economic freedom principles, the Yick Wo Court struck down a discriminatory state restriction on Chinese laundries. Unfortunately, the dualistic theory of civil rights did not long prevail on the Court. In subsequent decisions over the next twenty-two years, the Court protected only the occupational liberty aspect of civil rights.

This Note argues that the distinction the Supreme Court made between economic liberty cases and equal rights cases between 1886 and 1908 was a false one. In Part I, this Note summarizes the major equal rights/occupational liberty cases of the era and notes that the Court struck down facially neutral restrictions' on occupational liberty, but upheld explicitly discriminatory race and gender-based economic regulations. In Part II, the Note argues that when the Court protected occupational liberty by striking down facially neutral regulations it substantially advanced the economic prospects of Blacks, women, and immigrants. In other words, by protecting economic liberty, the Court also advanced equal rights. In Part III, the Note shows that when the Supreme Court upheld discriminatory economic regulations, it not only abandoned the principle of equal rights, but also dealt a blow to economic liberty. Part IV of the Note points out that the Court's turn-of-the-century bifurcation of the classic American vision of civil rights continues to this day, but in reverse; equal rights are currently protected, while occupational liberty is largely ignored. The Note concludes by calling for a revival of judicial protection of the occupational liberty part of the civil rights equation.

\section{CIVIL RIGHTS CASES BETWEen 1886 AND 1908}

\section{A. Yick Wo v. Hopkins}

Between 1886 and 1908, the Supreme Court decided several cases that raised issues of both equal rights and economic liberty. In the first of these cases, Yick Wo v. Hopkins, the Court upheld both the economic and equal rights of the plaintiff. In subsequent decisions, however, the Court began to uphold state economic regulations that explicitly discriminated against Blacks or women, even when such laws violated economic liberty principles. ${ }^{7}$ But when the Court had before it restrictions on occupational liberty with no racist or sexist component, it often struck down the challenged law. ${ }^{8}$ When the Court's hostility toward equal rights and its protection of economic liberty came into direct conflict in 1908 in Berea College v. Kentucky, the Court decided the

6. 118 U.S. 356 (1886).

7. See infra notes 14-22, 29-33 and accompanying text.

8. See infra notes $23-28,34-36$ and accompanying text.

9. 211 U.S. 45 (1908). 
case on a technicality, and thus was able to continue its "equal rights exception" to economic liberty.

Yick Wo involved a San Francisco ordinance which required wooden laundries to close. The ordinance was disguised as a fire protection measure, but it was actually a discriminatory rule designed to eliminate Chinese laundries, which were usually housed in wooden buildings. Not only was the law designed to harm disproportionately Chinese immigrants, but it also was administered unevenly, so that whites who owned wooden laundries managed to escape the force of the law, while the government prosecuted Chinese laundry owners.

Yick Wo, a Chinese laundryman, challenged the law. The Supreme Court, applying established civil rights principles, struck down the law. In its opinion, the Court initially emphasized that occupational liberty is of fundamental importance, particularly in light of the recent American experience with slavery:

[T] he very idea that one man may be compelled to hold his life, or the means of living, or any material right essential to the enjoyment of life, at the mere will of another, seems to be intolerable in any country where freedom prevails, as being the essence of slavery itself. ${ }^{10}$

The Court then ruled that the laundry law violated the equal protection component of the Fourteenth Amendment: "Though the law itself be fair on its face and impartial in appearance, yet, if it is applied and administered by public authority with an evil eye and an unequal hand . . . the denial of equal justice is still within the prohibition of the Constitution."11

These two excerpts from the Yick Wo opinion summarize the essence of the traditional American civil rights vision..$^{12}$ An individual of any race had the right to control his ${ }^{13}$ labor free from government interference and to be free from discriminatory treatment by the government. Unfortunately, racist doctrines soon conquered the legal world, and rather than establishing an important precedent for judicial protection of both equal rights and economic liberty, the Court's protection of equal rights in Yick Wo turned out to be an aberration.

\section{B. Plessy v. Ferguson}

In the 1880's and 1890's, state ordinances requiring the public segregation of Blacks and whites began to spring up across the United States. Among these ordinances was a Louisiana railroad car segregation law that the Supreme Court

10. 118 U.S. at 370 (emphasis added).

11. Id. at 373-74.

12. C. BolicK, supra note 1 , at 128-29.

13. In at least some circles, civil rights were thought to extend to women as well as to men. See, e.g., Ritchie v. People, $155 \mathrm{Ml} .98$ (1895) (women have same constitutional right to freedom of contract and same natural right to occupational liberty as men). 
sustained against a Fourteenth Amendment challenge in the now infamous case of Plessy v. Ferguson. ${ }^{14}$ The Court used broad, sweeping language that seemed to deny that any manner of segregation law would violate the Fourteenth Amendment:

[Plessy's] argument also assumes that social prejudices may be overcome by legislation, and that equal rights cannot be secured to the negro except by an enforced commingling of the two races. We cannot accept this proposition. If the two races are to meet upon terms of social equality, it must be the result of natural affinities, a mutual appreciation of each other's merits and a voluntary consent of individuals. ${ }^{15}$

The problem with the Court's argument is that Plessy, the "Negro"16 plaintiff, was not asking anyone to "enforce" the "commingling of the races." $\mathrm{He}$ was simply asking that the Court not allow the State of Louisiana to prohibit whites and Blacks from interacting on trains when the train company itself allowed such interaction. Despite the Court's thetoric, Blacks and whites did interact in public to a large extent before the Plessy decision, ${ }^{17}$ including on trains, ${ }^{18}$ and it was only the state-enforced Jim Crow laws that led to a rigid system of segregation in the South. ${ }^{19}$

Thus, the Court's claimed deference to custom was a ruse. This claim might have made sense if Louisiana forced unwilling train companies and individuals to integrate, but the law instead required companies to enforce segregation. The Court's actual motivation appears later in the decision, when it states that "[l]egislation is powerless to eradicate racial instincts or to abolish distinctions based upon physical differences ...."20 While still paying lip service to custom, the Court revealed its actual motivation to be the crude (although then popular) set of racist nostrums that saw Blacks as an inferior, almost subhuman race. $^{21}$

While the Plessy Court allowed state police power to run rampant in the name of segregation against the economic liberty of train owners and passen-

14. 163 U.S. 537 (1896).

15. Id. at 551 .

16. Plessy had one Black great-grandparent, enough to be considered a Negro under the applicable statute.

17. See C. WoOdWard, The Strange Career of JM Crow 36-43 (3d ed. 1974).

18. Id. at 38-40. Railroad companies often opposed segregation laws because of the expense involved in enforcing them. Epstein, Race and the Police Power: 1890 to 1937, 46 WASH. \& LEE L. REV. 741, 747 (1989) (explaining economic costs involved in enforcing segregation on railroads).

19. See infra notes 88-95 and accompanying text; see also C. WOODWARD, supra note 17 , at $33-34$ (segregation on trains and streetcars was becoming progressively rarer until, in wake of Plessy, laws mandating segregation passed).

20. Plessy, 163 U.S. at 551.

21. See generally Hovenkamp, Social Science and Segregation Before Brown, 1985 DUKE L.J. 624 (discussing late 19th century and early 20th century "scientific" theories used as justification for segregation). 
gers, ${ }^{22}$ the court soon began to recognize the right of individuals to contract freely in the context of government regulations that did not involve explicit racial issues.

\section{Freedom of Contract Cases}

In Allgeyer v. Louisiana, ${ }^{23}$ a case involving regulations on insurance companies, a unanimous Supreme Court held that the liberty interest protected by the Fourteenth Amendment's due process clause included freedom of contract. The most famous case applying this principle is Lochner $v$. New York. ${ }^{24}$

Lochner involved a challenge to a New York statute that prohibited employers from employing a baker for more than sixty hours per week. New York State asserted that since an individual's labor ultimately belongs to the state, the state has a right to regulate working conditions:

The State, in undertaking this regulation, has a right to safeguard the citizen against his own lack of knowledge. In dealing with certain classes of men the State may properly say that, for the purpose of having able-bodied men at its command when it desires, it shall not permit these men, when engaged in dangerous or unhealthful occupations, to work for a longer period of time each day than is found to be in the interest of the health of the person upon whom the legislation acts. $^{25}$

In a stirring defense of individual liberty and civil rights principles, the majority of the Supreme Court Justices rejected arguments that the citizen is ultimately beholden to the government and that the government has the right and duty to protect an individual from exercising freedom of choice. The Court stated that it must "determine which shall prevail-the right of the individual to labor for such time as he may choose, or the right of the State to prevent the individual from laboring or from entering into any contract to labor, beyond a certain time prescribed by the State."26

The Court added that if New York's statist argument succeeded:

Not only the hours of employes, but the hours of employers, could be regulated, and doctors, lawyers, scientists, all professional men, as well as athletes and artisans, could be forbidden to fatigue their brains and bodies by prolonged hours of exercise, lest the fighting strength of the State be impaired. ${ }^{27}$

22. See Epstein, supra note 18.

23. 165 U.S. 578 (1897).

24. 198 U.S. 45 (1905).

25. $I d$. at $\mathbf{S 1}$ (argument for defendant in error) (emphasis added).

26. Id. at 54 .

27. Id. at 60-61. 
The Court's opinion signaled the start of the "Lochner era," in which the Court cast a skeptical eye toward economic regulation, particularly if it interfered with occupational liberty. ${ }^{28}$ Support for the principle of constitutional protection for freedom of contract and occcupational liberty was nearly unanimous on the Court. With the exception of Justice Holmes' lone opinion, the dissenters did not deny that the due process clause of the Fourteenth Amendment protected occupational liberty. Instead, they expressed their belief that the statute in question was a valid health measure under the police power, and was therefore not constitutionally infirm.

Despite the Court's Lochner ruling, in 1908 in Muller v. Oregon ${ }^{29}$ the Court sustained an Oregon law prohibiting women from working more than ten hours per day in factories or laundries. The Court upheld the law on the grounds that women need special protection from physical labor ${ }^{30}$ because they are not physically capable of competing with men in the labor market. Moreover, according to the Court, the public has a particular interest in women's health because healthy mothers are needed "to preserve the strength and vigor of the race."31 Ironically, the public interest language of this decision is reminiscent of the New York State argument rejected by the Court in Lochner. ${ }^{32}$ What differentiates Muller from Lochner is the Court's acceptance of the state's contention that the statute was a health measure, not a labor statute meant to aid some workers at the expense of others, and thus was a valid exercise of the police power. ${ }^{33}$

In another 1908 case, Adair v. United States, ${ }^{34}$ the Court, relying heavily on Lochner, struck down a federal law banning interstate railroads from enforcing "yellow dog" contracts" against their employees on economic liberty grounds. Adair, the chief of operations of the Louisville and Nashville Railroad, was prosecuted for firing a worker who had joined a union in violation of his contract with the railroad. In overturning Adair's indictment, Justice Harlan wrote that the flip side of freedom of contract for the individual worker is the equal freedom of the employer "to prescribe the conditions upon which he will accept such labor from the person offering to sell it."36

28. See Epstein, A Common Law for Labor Relations: A Critique of the New Deal Labor Legislation, 92 YALE L.J. 1357, 1362 n.17 (1983) (Lochner era Supreme Court struck down legislation benefiting unionized labor at expense of nonunion labor, but did not strike down legislation that redistributed income from rich to poor).

29. 208 U.S. 412 (1908).

30. Id. at 422 .

31. Id. at 421 .

32. See supra note 25 and accompanying text.

33. This supports Richard Epstein's argument that the ultimate flaw in the Lochner opinion is that it gave too much scope to the police power and too little protection to economic liberty. Epstein, supra note 18.

34. 208 U.S. 161 (1908).

35. A yellow dog contract forbids an employee to join a union.

36. Adair, 208 U.S. at 174. 


\section{Berea College: Occupational Liberty versus Segregation}

The tension between the Court's refusal to protect equal rights and its protection of economic liberty culminated in Berea College v. Kentucky. ${ }^{37}$ Berea College, a small, private, racially integrated school, was the only institution of higher learning in Kentucky that accepted Blacks apart from the Kentucky State Industrial College. ${ }^{38}$ The Kentucky Day Law, passed during the 1904 legislative session, prohibited the instruction of Black and white students in the same school, whether private or public. ${ }^{39}$ The law clearly was aimed directly at Berea College.

The college challenged the law unsuccessfully throughout the Kentucky judicial system, and the case finally reached the United States Supreme Court. The college hoped that the right to pursue the occupation of private school teaching without unreasonable governmental interference would follow logically from the earlier freedom of contract cases. ${ }^{40}$ Citing Yick Wo, Allgeyer, and Lochner, Berea argued that "a private school stands on exactly the same footing as any other private business .... The statute is ... an arbitrary interference with the rights of the people in the conduct of their private business and in the pursuit of their ordinary occupations." ${ }^{41}$

The State of Kentucky responded as the State of New York had in Lochner: "The welfare of the State and community is paramount to any right or privilege of the individual citizen. The rights of the citizen are guaranteed, subject to the welfare of the State." ${ }^{\prime 2}$

In ruling against the college, the Court upheld the law on the narrowest possible grounds. ${ }^{43}$ It sidestepped the inherent contradiction between forced segregation and freedom of contract by ruling that because Berea College was established under state charter, the state could regulate it in any way it chose as long as the regulation did not violate the original intent of the charter ("the education of all persons who may attend"). ${ }^{44}$ Justice Brewer, writing for the Court, pointed out that the college could still educate all persons, as long as Blacks and whites were separated..$^{45}$

37. 211 U.S. 45 (1908).

(1990).

38. Roback, Rules v. Discretion: Berea College v. Kentucky, 20 INT'L J. GROUP TENSIONS 47, 51

39. Public schools had been segregated since their inception. Id. at 50 .

40. 9 A. BICKEL \& B. SCHMIDT, THE OLIVER WENDELL HOLMES DEVISE HISTORY OF THE SUPREME COURT OF THE UNITED STATES 731 (1984).

41. Berea, 211 U.S. at 48 (argument for plaintiff in error).

42. Id. at 51 (argument for defendant in error).

43. Schmidt, Principle and Prejudice: The Supreme Court and Race in the Progressive Era. Part 1: The Heyday of Jim Crow, 82 CoLUM. L. REV. 444, 452 (1982).

44. Berea, 211 U.S. at 56. The Court hinted that the law might have been unconstitutional had it been applied to an individual rather than a corporation, but the Court did not explicitly consider that question. Id. at 54. Despite Berea's direct challenge, the Court did not mention Lochner at all.

45. Id. at 57 . 
As in Plessy, the lone dissenter in Berea College was Justice Harlan. In Plessy, Harlan had based his opposition to a segregation statute on a defense of equal rights. In Berea College, however, his opposition rested on a defense of economic liberty. He wrote:

The right to impart instruction ... is, beyond question, part of one's liberty as guaranteed against hostile state action by the Constitution of the United States. This court has more than once said that the liberty guaranteed by the Fourteenth Amendment embraces "the right of the citizen to be free in the enjoyment of all his faculties," and "to be free to use them in all lawful ways." ${ }^{46}$

Harlan was the only Justice who sought to protect both halves of the civil rights equation as expressed in Yick Wo.

The Yick Wo decision implied that the Supreme Court would protect basic traditional freedoms, both "economic liberty" and "equal rights," on behalf of all residents of the United States. In Lochner, the Court indicated that when a statute applied to all workers, it was still willing to protect economic rights from arbitrary governmental intrusion. By the time Berea was decided in 1908, however, it was clear that the Court had decided to uphold governmental economic regulation directed against Blacks and women.

This apparent paradox becomes somewhat less puzzling when we consider the prevailing ideology of race of that time:

[A]mong biologists, sociologists and social anthropologists as well as journalists and political commentators, the assumptions ... that races were discrete entities and that the white or "Caucasian" race was superior ... were taken for 'granted. ...

$\ldots$.

... Thus, in the same fashion that an intelligent zoo keeper separates the lions and the elephants in different compounds, the Supreme Court endorsed the proposition that biologically distinct Negroes and whites need not be given identical treatment. ${ }^{47}$

Similarly, the Court's decision in Muller reflected the dominant sentiment of the day that women were the inferior sex and thus needed special protec-

46. Id. at 67-68 (Harlan, J., dissenting) (quoting Allgeyer, 165 U.S. at 589).

47. Roche, Civil Liberty in the Age of Enterprise, 31 U. CHI. L. REV. 103, 116 (1963). 
tion. $^{48}$

As this Note will argue in the next two sections, by enforcing freedom of contract in the workplace, the Court promoted the interests of minorities, immigrants, and women. On the other hand, when the Court ignored equal rights and upheld segregation statutes, it not only harmed Blacks, but also succeeded in subverting the market order it otherwise claimed to be protecting.

\section{Freedom of Contract as Protection of CiviL Rights}

In a truly free market, all have an equal right to buy and sell their labor to the highest bidder. Anyone who wants to discriminate must pay an economic cost by either acquiring an inferior employee or paying a higher wage. Indeed, Gary Becker's influential book, The Economics of Discrimination, argues that in a pure market environment invidious employment discrimination would tend to disappear as economic forces overcame discriminatory preferences. ${ }^{49}$

The political marketplace, however, operates under different rules. Rather than having to pay an economic price for discrimination, people who prefer discrimination need only pay with a vote. Discriminatory legislation not only satisfies voters' prejudices, but can also operate to the economic advantage of the politically dominant group.

Around the turn of the century Blacks, women, and immigrants were largely disenfranchised. As one would logically expect, labor legislation passed at that time tended to benefit politically dominant native white males at the expense of these groups.

Consequently, the Supreme Court's general pattern of upholding freedom of contract against legislative interventions promoted by enfranchised white males benefitted the politically disadvantaged. When the Court stepped in to preserve this freedom in Yick Wo, Lochner, and Adair, the prime beneficiaries were members of the disenfranchised classes. But when the Court refused to intervene, as in Muller and Berea, the consequences for the politically powerless were devastating.

48. For an early critique of the sexism in Muller, see Note, Constitutional Law-Regulation of Conditions of Employment of Women: A Critique of Muller v. Oregon, 13 B.U.L. REV. 276 (1933).

49. G. BECKER, THE ECONOMICS OF DISCRIMINATION (2d ed. 1971). Becker has been criticized on the grounds that his thesis seems to be contradicted by evidence showing long-run earnings differences between different American ethnic groups. It should be noted, however, that the United States does not operate (and has never operated) in a pure market environment. Roback, Southern Labor Law in the Jim Crow Era: Exploitative or Competitive?, 51 U. CHI. L. REV. 1161, 1163 (1984). Moreover, cultural factors may play a large role in determining ethnic groups' incomes. See generally T. SOWELL, ETHNIC AMERICA 282-84 (1981) (ethnic group's culture and history are significant factors in determining its economic status in society). While one might take issue with the extreme version of the Becker thesis, the profit motive in a free market clearly does create disincentives for discrimination. 


\section{A. Yick Wo v. Hopkins and the California Labor Market}

The highly competitive California labor market served as the historical backdrop for Yick Wo v. Hopkins. White union leaders and members believed that Chinese immigrant workers were undercutting their wage demands. ${ }^{50}$ The Union Labor Party and its allies therefore sponsored a racist "Chinese Must GO!" political campaign. ${ }^{51}$ The initial legislative result of this campaign was a law prohibiting California corporations from hiring Chinese laborers. That law was struck down by a federal circuit court. ${ }^{52}$ Despite that failure, the racial hatred stirred up by the unions gave other interest groups an opportunity to use anti-Chinese sentiment to their own advantage. While the actual origins of the laundry law are somewhat hazy, Circuit Judge Sawyer wrote of it:

The necessary tendency, if not the specific purpose, of this ordinance, and of enforcing it in the manner indicated in the record, is to drive out of business all the numerous small laundries, especially those owned by Chinese, and give a monopoly of the business to the large institutions established and carried on by means of large associated Caucasian capital..$^{53}$

Regardless of whether Sawyer correctly pinpointed the origins of the law, it is probable that both the racial hatred stirred by the white unions and the economic interests of the California elite ${ }^{54}$ played major roles in the passage of the law. In any event, the law, though facially neutral, was clearly designed to harm Chinese immigrants, and it would have had that effect whether administered neutrally or not.

\section{B. Lochner: Protection for Immigrant Bakers}

While the Yick Wo decision still stands as a much-praised early example of a civil rights victory, Lochner v. New York is one of the most reviled cases of all time. According to one scholar, Lochner and its progeny have been "virtually universally rejected on sound political-moral grounds" and are now

50. See generally A. SAXTON, THE INDISPENSABLE ENEMY: LABOR AND THE ANTI-CHINESE MOVEMENT IN CALIFORNIA (1971) (outlining conflicts between unions and immigrants).

51. Roche, supra note 47 , at 122.

52. In re Tiburcio Parrott, 1 F. 481 (C.C.D. Cal. 1880). (1886).

53. In re Wo Lee, 26 F. 471, 474 (C.C.D. Cal.), aff' $d$ sub nom. Yick Wo v. Hopkins, 118 U.S. 356

54. John Roche asserts that the law was struck down as a favor to California's "great corporate figures" who were trying to bust the unions. Roche, supra note 47 , at 122 . But it is difficult to see how allowing independent Chinese laundries to operate, thus contracting the potential manual labor supply, could have helped California businessmen or hurt unions. On the contrary, removing Chinese immigrants from the potential manual labor pool would logically result in an increase in white workers' bargaining power. 
the subject of "widespread condemnation." 55 Yet, as we shall see, the fact patterns of Yick Wo and Lochner were very similar.

Most scholars who study Lochner misunderstand the decision. This misunderstanding arises from the belief that the law in question in Lochner was enacted out of a desire to help downtrodden workers who, because of their weak bargaining position, could not help themselves. ${ }^{56}$ Thus, the Lochner decision is supposedly "vulnerable to the claim that [it] benefitted established economic interests at the expense of the relatively powerless. ${ }^{.57}$

Part of this misunderstanding derives from the language of the majority decision, which said that the maximum hours law under review was not a health measure, but was "passed from other motives." 58 Many scholars have taken this to mean that the majority disapproved of the law because the real motive behind it was to redistribute wealth..$^{59}$ There is, however, no economic reason why passing maximum hours laws would necessarily result in higher overall wages for bakers. ${ }^{60} \mathrm{~A}$ worker who must toil fewer hours generally will get paid proportionally less.

Moreover, as Justice O'Brien pointed out in his dissent at the state level, the bakery statute did not actually restrict hours worked. Under the statute, as long as no baker worked more than sixty hours in a single bakery, "[n]o restrictions are imposed upon the servant with respect to the hours of labor or otherwise. . . . [H]e has a perfect right to work as many hours in a day or week as he may want to ...."

If the motivation behind the law was not to redistribute income, nor (because it did not actually restrict hours worked) to protect the health of the worker, ${ }^{62}$ then what were the "other motives" referred to by the Court? As

55. M. PERRY, THE CONSTITUTION, THE COURTS, AND HUMAN RIGHTS: AN INQUIRY INTO THE LEGITIMACY OF CONSTITUTIONAL POLICY MAKING BY THE JUDICIARY 115-16 (1982). This bit of conventional wisdom has, however, recently come under attack. See, e.g., Phillips, Another Look At Economic Substantive Due Process, 1987 WIS. L. REv. 265, 266 n.7 (citing pro-Lochner articles).

56. See, e.g., G. GUNTHER, CONSTITUTITIONAL, LAW 569 (9th ed. 1975) (Lochner bakery law was "designed to protect bakery workers in an unequal bargaining position"); Bell, Does Discrimination Make Economic Sense?, 15 HUMAN RIGHTS 38, 41-42 (1988) (just as Plessy harmed disadvantaged Blacks by upholding segregation ordinance, Lochner harmed "powerless" and "exploited" whites by striking down protective labor legislation).

57. Phillips, supra note 55 , at 275.

58. Lochner, 198 U.S. at 64.

59. See, e.g., Balkin, Ideology and Counter-Ideology from Lochner to Garcia, 54 UMKC L. REV. 175, 185 (1986) (Lochner Court was motivated by desire to prevent state legislatures from redistributing income from rich to poor). But cf. Epstein, supra note 28.

60. Indeed, this applies, if not as obviously, to all labor legislation. L. VON MISES, HUMAN ACTION 617 (1949) (overall, labor legislation and union pressure do not help workers and may actually harm them by causing wages to rise faster than capital accumulation).

61. People v. Lochner, 177 N.Y. 145, 177, 69 N.E. 373, 385 (1904) (O'Brien, J., dissenting).

62. Another piece of evidence that the statute in question was not truly a health measure is the fact that approximately $50 \%$ of bakers, apparently those not in direct competition with large unionized bakeries, were exempted from the statute's provisions. Karlin, Back to the Future: From Nollan to Lochner, 17 Sw. U.L. REV. 627,669 (1988). 
in Yick Wo, the political force behind the legislation in question was hostility to competition in the labor market from immigrants:

Many workers in the small bakeries of New York City, and probably elsewhere in the state, were recent immigrants unable to speak English, who were attracted to owners speaking their language .... The time limitation on working hours would have forced the small owners to hire additional help.... Consequently the restrictions on working hours meant higher labor costs for the small bakers ..... A number of the small bakers would have to terminate their businesses. ${ }^{63}$

Most small, immigrant-owned and operated, nonunion bakeries could not survive under a maximum hours regime. Workers in these bakeries would prepare the bread in the evening, put it in the ovens, and then sleep until morning when they removed the bread. ${ }^{64}$ The high fixed costs to employers of providing shelter to the workers could only be offset by a long working day. Not surprisingly, large bakers supported the law in order to reduce competition..$^{65}$ Bakers' unions also supported the law ${ }^{66}$ Because unionized bakers already generally worked fewer than sixty hours a week, ${ }^{67}$ and thus did not need the law to reduce their hours, their obvious goal was to try to reduce competition from nonunionized, immigrant bakers in the hope that the constriction in the supply of bakery labor would lead to higher wages for union members. ${ }^{68}$ Therefore, in striking down New York's maximum hours law, the Supreme Court protected not only occupational liberty, but also the equal rights of immigrant laborers against discriminatory legislation. ${ }^{69}$

\section{Muller: The Court Fails to Protect Women and Immigrants}

Three years after Lochner, the Supreme Court failed to protect occupational liberty in Muller. Aided by the now infamous "Brandeis Brief," which detailed the alleged ill health effects of long hours of labor on women, the Court saw the law more as a regulatory measure aimed at preserving women's health than the actual threat to women's economic liberty that it was. Unfortunately, women's rights received the same short shrift as other equal rights issues of

63. B. SIEGAN, ECONOMIC LIBERTIES AND THE CONSTTTUTION 117 (1980).

64. Epstein, Self-Interest and the Constitution, 37 J. LEGAL EDUc. 153, 158 n.6 (1987).

65. B. SIEGAN, supra note 63, at 350 n.29 and accompanying text; Epstein, The Mistakes of 1937, 11 GEO. MASON U.L. REV. 5, 17 (1988) ("The statute was championed by rival unions and their employers .....").

66. Epstein, supra note 65.

67. B. SIEGAN, supra note 63 , at 117-18.

68. Epstein, supra note 65, at 158 \& n.6; Note, supra note 5, at 1372.

69. The Lochner majority did not explicitly state that it was protecting the rights of immigrants and not simply the abstract freedom to contract. However, the Court did say that " $[t]$ he purpose of a statute must be determined from the natural and legal effect of the language employed," and it cited Yick Wo, another case involving discrimination against immigrants, for the proposition that " $[\mathrm{t}] \mathrm{he}$ court looks beyond the mere letter of the law in such cases." Lochner, 198 U.S. at 64. 
the period. The Court therefore upheld the law, which was representative of a popular form of legislation that served to prevent women from competing in the workforce. ${ }^{70}$

In Lochner, the Supreme Court's protection of freedom of contract preserved economic opportunity for immigrants. The Court's acquiescence to the spread of restrictive labor legislation against women in $M$ uller ${ }^{71}$ on the other hand, deprived women and especially immigrant women of the opportunity to compete in the labor market. ${ }^{72}$

\section{Adair: Protection of Blacks From Union Discrimination}

The principles of freedom of contract and occupational liberty, when enforced by the Court as in Lochner, protected the equal rights of immigrants. Similarly, in Adair the Court protected the rights of Blacks by enforcing freedom of contract. Indeed, the Adair decision was perhaps the most favorable decision regarding the equal rights of Blacks made by the Court until Brown v. Board of Education of Topeka. ${ }^{73}$ The Adair decision not only benefited Blacks by preventing racist white unions from monopolizing the interstate railroad labor market, ${ }^{74}$ it also set a precedent that precluded the possibility of further, more restrictive, pro-organized labor legislation. The decision thus gave Blacks a respite from the destructive effects of labor unions on their employment prospects. ${ }^{75}$

70. See Taylor, Protective Labor Legislation, in FREEDOM, FEMINISM, AND THE STATE 267 (W. McElroy ed. 1982) (protective legislation for women served to keep them out of well-paying jobs).

71. After Muller, even state courts that had previously struck down maximum hours laws for women upheld them. Compare Ritchie v. People, 155 Ill. 98 (1895) (striking down maximum hours law for women) with W.C. Ritchie \& Co. v. Wayman, 244 Ill. 509 (1910) (upholding maximum hours law for women). For a discussion of other state cases, see Note, supra note 48 .

72.

Maximum-hours laws . . . reduced not only women's hours of work in 1920 but their employment as well. Further, the effect was not uniform by race and nativity: While the employment of foreign-born women was significantly reduced -by as much as 30 percent in the most restrictive states-the employment of native white women was largely unaffected.

Landes, The Effect of State Maximum-Hours Laws on the Employment of Women in 1920, $88 \mathrm{~J}$. POL. EcoN. 476,476 (1980). Landes points out that organized labor was the prime lobbyist for such laws nationwide. Id. at 489 .

73. 347 U.S. 483 (1954).

74. See Williams, Freedom to Contract: Blacks and Labor Organizations, Gov'T UNION REV., Summer 1981, at 28, 31-32 (discussing harm done to Blacks by banning of yellow dog contracts under Railway Labor Act, as amended in 1934).

75. White unions excluded Blacks from such union positions as "electricians, plumbers, gas and steamfitters, railroad engineers and firemen, stationary engineers, cranemen, hoistmen, machinists, and hundreds of other skilled and semi-skilled occupations." 3 P. FONER, HISTORY OF THE LABOR MOVEMENT IN THE UNITED STATES: THE POLICIES AND PRACTICES OF THE AMERICAN FEDERATION OF LABOR, 19001909, at 240 (1981). By 1912, outside of the United Mine Workers, with 40,000 Black members, the largest Black membership in an American Federation of Labor union was 6,000. And far more typical were the Pressmen, Lithographers, Photo-Engravers, Iron, Steel and Tin Workers, Potters, Glass Botttle Blowers, Hatters, Molders, Pattern Makers, Glass Workers, Boot and Shoe Workers, and Wood Workers unions, each of which had between zero and a dozen Black members. Id. at 254; see generally id. at 233-55 (discussing discriminatory union policies); H. HILL, BLACK LABOR AND THE AMERICAN LEGAL SYSTEM (1977) 
Union policies had especially harmful effects on Blacks in the South. ${ }^{76}$ For example, as late as the early 1890 's, Blacks constivuted a high percentage of skilled workers in the southern building and railroad industries. ${ }^{77}$ But because of exclusionary union policies in the South which later spread to other parts of the country, by 1950 Black participation in these fields had sunk to insignificant levels. ${ }^{78}$ Blacks were banned from union apprenticeship programs, and the few who managed to acquire skills despite the obstacles had to work at nonunion jobs.

Southern states furthered the unions' goals by passing laws requiring apprenticeships before a worker could practice a craft. ${ }^{79}$ Some of the laws were explicitly discriminatory while others were facially neutral but were actually intended to restrict Blacks' access to the labor market. ${ }^{80}$ Southern states also frustrated Blacks' opportunity to attain skilled positions by banning them from public vocational schools, ${ }^{81}$ in effect subsidizing only white workers' training. Other governmental intrusions into the labor market in the South severely restricted Black workers' opportunities in unskilled labor as well. ${ }^{82}$

Despite the efforts of racists and opportunists to restrict the market for Black labor, because of the general freedom of contract regime that existed around the time of Lochner and Adair, an extremely high $71 \%$ of Blacks were employed in $19100^{83}$ Significant disparities in Black and white unemployment rates did not occur until after the Supreme Court upheld the major New Deal labor legislation of the 1930's. ${ }^{84}$

In general, when freedom of contract was judicially protected, it was a boon to immigrants ${ }^{85}$ and Blacks. ${ }^{86}$ The fact that women could not contract freely,

(historical overview).

76. Southern labor policies are especially important to study for the period under consideration in this Note because the vast majority of Blacks lived in the South at this time. However, the northern unions, which were far more powerful than their southern counterparts, did not necessarily treat Blacks any better. Higgs, Black Progress and the Persistence of Racial Economic Inequalities, 1865-1940, in THE QUESTION OF DISCRIMINATION 9, 23 (W. Darity \& S. Shulman eds. 1989).

77. P. FONER, supra note 75 , at 238.

78. $I d$.

79. See generally G. STEPHENSON, RACE DISTINCTIONS IN AMERICAN LAW 53-58 (1910) (discussing apprenticeship laws).

80. Id. at 53 ("T]t is scarcely open to argument that, in making such laws, [the legislatures] did not have in mind primarily Negroes.").

81. P. FONER, supra note 75 , at 240.

82. See generally Roback, supra note 49 (discussing enticement and contract enforcement laws, vagrancy laws, emigrant-agent laws, and the convict-lease system). Professor Roback concludes that "[e]xploitation was not inherent in the capitalist system; rather, government power had to be specifically mobilized to achieve this end." Id. at 1163 . She adds that "the evidence indicates that the law, not the market, was the chief oppressor of blacks in the Jim Crow period." Id. at 1192.

83. W. WILliAMS, THE STATE AgaINST BLACKS 43 (1982) (in 1910, 71\% of Blacks over nine years of age were employed compared with $51 \%$ of whites).

84. H. Hinl, supra note 75 , at 96 .

85. See supra notes 50-69 and accompanying text; see also T. SOWELI, MARKETS AND MRNORIIES 111 (1981) (opportunity to work in "sweatshops" provided necessary entry-level opportunities for Jewish immigrants). 
meanwhile, severely restricted their opportunities in the labor market. ${ }^{87}$ Despite the progressive-sounding thetoric that usually accompanied it, legislation enforcing restrictions on contract was generally reactionary special interest legislation meant to preserve the power and prerogatives of the existing elite. Economic freedom and equal rights went hand in hand.

\section{SEgREgATION LAWS v. ECONOMIC FREEDOM}

Rigid segregation, this section argues, was a product of government, rather than market-enforced custom. This theory is a controversial one. Many scholars assume that if a segregation ordinance is passed, it must be because a majority of the voters strongly desire segregation. ${ }^{88}$ They therefore conclude that segregation would have occurred with or without government prompting. The theories of public choice economics, ${ }^{89}$ however, lead to the opposite conclusion. According to leading public choice economists, legislation is passed when "collective action" problems arise such that voluntary actions will not accomplish the goals of a group. ${ }^{90}$ When voluntary efforts fail, groups turn to government to enforce their goals via state coercion.

\section{A. Segregation and Common Carriers}

In her study of streetcar segregation in the South, Professor Jennifer Roback shows that streetcars across the South were integrated before the government intervened. ${ }^{91}$ White passengers may have had a preference for segregation, but Black passengers were virulently opposed to it, and often would launch boycotts against segregated lines. ${ }^{92}$ The streetcar owners were concerned with maximizing revenues, and Roback notes that "[s] egregation is profit maximizing [only] if the revenue gained from white passengers outweighs the lost revenue from black passengers and the direct costs of providing segregation." ${ }^{93}$ Blacks were willing to boycott segregated cars, but whites were not willing to boycott integrated ones. Therefore, as economic theory would predict, the cars remained integrated.

86. See supra notes 73-84 and accompanying text; see also Williams, supra note 74 , at 28-47; cf. M. FRIEDMAN, CAPITALISM AND FREEDOM 109 (1962) ("The maintenance of the general rules of private property and of capitalism have been a major source of opportunity for Negroes . ....).

87. See supra notes $69-72$ and accompanying text.

88. See infra note 98 .

89. See generally D. MUELLER, PUBLIC CHOICE (1978) (overview of public choice theory).

90. See generally M. OLSON, THE LOGIC OF COLLECTIVE ACTION (1965) (classic work on collective action problem).

91. Roback, The Political Economy of Segregation: The Case of Segregated Streetcars, 46 J. EcoN. Hist. 893 (1986).

92. The best account of those boycotts is Meier \& Rudwick, The Boycott Movement Against Jim Crow Streetcars in the South, 1900-1906, 55 J. AM. HIST. 756 (1969).

93. Roback, supra note 91 , at 896. 
However, once the Supreme Court allowed state-mandated segregation in the railroad cases, the cost to prejudiced whites of fulfilling their preference for segregation dropped from the costs of launching an organized boycott or paying a higher fare to the price of a vote. White citizens unwilling to pay a private price to ride in a segregated car voted for candidates who favored segregation laws. Through the democratic process, the costs of segregation were imposed on the disenfranchised Black passengers and the regulated streetcar companies. ${ }^{94}$

Plessy and the other train segregation cases ${ }^{95}$ are difficult examples to incorporate in this analysis because railroads, with their state charters and special privileges, were pure monopolies, ${ }^{96}$ and railroad travel was indispensable to long-distance travelers and therefore difficult to boycott. ${ }^{97}$ The extent of segregation on common carriers around the time that Plessy was decided is still an open question..$^{98}$ However, there is no doubt that at least some common carriers would have remained integrated had they not been subject to government-ordered segregation. Indeed, the arrest of Plessy was apparently prearranged by the company and the civil rights group planning to challenge it. ${ }^{99}$ Other examples of corporate resistance to segregation ordinances abound as well. ${ }^{100}$

In any event, Plessy had a significance well beyond its implications for segregation on railroads and other common carriers. The depth of the racism

94. Roback, Racism As Rent-Seeking, 27 ECON. INQUIRY 661, 674 (1989); Roback, supra note 91, at 897-98. In at least one city, Houston, Black entrepeneurs started jitneys in competition with the segregated streetcars. Dressman, "Yes, We Have No Jitneys!" Transportation Issues in Houston's Black Community, 1914-1924, 9 HOUSTON REV. 69, 73 (1987). In 1922, the Black-owned jitneys were ordered by the city to discontinue service. $I d$. at 76.

95. See infra note 100 .

96. Cf. Maltz, "Separate But Equal" and the Law of Common Carriers in the Era of the Fourteenth Amendment, 17 RUTGERS L.J. 553 (1986) (Plessy cannot be properly understood without reference to special rules under which common carriers operated).

97. When serious competition later arrived in the form of cross-country buses, the Jim Crow train laws were promptly extended to buses as well. C. WOODWARD, supra note 17 , at 116 .

98. In The Plessy Case, Charles Lofgren concludes that voluntary segregation was increasing. His conclusion apparently relies on the fact that segregation laws began to be passed around 1890. C. LOFGREN, THE PLESSY CASE 7-17 (1987). Such evidence leads Professor Roback to the opposite conclusion, however. She says that segregation laws must have been a product of the fact that segregation was not happening voluntarily. If segregation had been the rule, laws enforcing segregation would not have been needed. Telephone interview with Jennifer Roback, Professor of Economics, George Mason University (Sept. 6, 1989). Lofgren suggests that a case by case study is needed to discover whether segregation resulted from custom or law. C. LOFGREN, supra, at 17. Professor Roback conciuded her study of the streetcars of various southern cities with the finding that "[i]t is unlikely that practice anticipated law in this area." Roback, supra note 91 , at 916.

99. See Oberst, The Strange Career of Plessy v. Ferguson, 15 ARIZ. L. REV. 389, 393 (1973).

100. See, e.g., Chesapeake \& O. Ry. v. Kentucky, 179 U.S. 388 (1900) (railroad challenges Kentucky segregation law on ground that it violated commerce clause); Louisville, N.O. \& Tex. Ry. v. Mississippi, 133 U.S. 587 (1890) (railroad challenges Mississippi segregation law on commerce clause grounds); Smith v. State, 100 Tenn. 494 (1898) (conductor refuses to assign Blacks to segregated car); Roback, supra note 93, at 894 ("[T]he streetcar companies frequently resisted segregation, both as custom and law."); id. at 899-906, 909, 913 (resistance to segregation ordinances by railway companies in Georgia, Florida, and Alabama). 
and the broad language in Plessy gave local governments the legal green light to pass all manner of laws regulating the racial policies of private businesses. In the years following Plessy, laws segregating everything from hospitals to tent shows to fraternal societies were passed throughout the South. ${ }^{101}$

\section{B. The Showdown Between Economic Freedom and State-Enforced Segregation}

Forced segregation laws represented perhaps the most egregious governmental violation of the rights to property and freedom of contract between the Civil War and the New Deal era. It was therefore only logical that a challenge to such laws on economic liberty grounds would soon arise, as it did in Berea College. ${ }^{102}$

Berea College's Supreme Court argument also posed a direct challenge to the logic of the majority opinion in Plessy ${ }^{103}$ by pointing out that the Kentucky law prohibited completely voluntary interaction between the races:

Social equality between persons of the white and colored races, or between persons of the same race, cannot be enforced by legislation, nor can the voluntary association of persons of different races, or persons of the same race, be constitutionally prohibited by legislation unless it is shown to be immoral, disorderly, or for some other reason so palpably injurious to the public welfare as to justify a direct interference with the personal liberty of the citizen; and even in such a case the restriction should go no further than is absolutely necessary. ${ }^{104}$

While this argument did not succeed with the Court, the importance of this point cannot be overestimated. Alternative histories are easy to imagine and impossible to prove, but there can be little doubt that had the Supreme Court applied the principles of economic liberty to facially discriminatory statutes, segregation-and discrimination against Blacks in general-would have been far less onerous. ${ }^{105}$ Thus, the acquiescence of the Supreme Court to the denial of economic liberty in the form of segregation laws contributed to the establishment of Jim Crow in areas where it would never have spread had the free market been allowed to operate.

101. C. WOODWARD, supra note 17 , at $98-100$.

102. Professor Roback points out that Berea College "illustrates that at least [one] aspect of the southern segregation system was based upon [government] intervention into the market order, rather than on the market order itself." Roback, supra note 38 , at 61 .

103. See supra notes $15-21$ and accompanying text.

104. Berea, 211 U.S. at 50 (argument for plaintiff in error).

105. Even a scholar as hostile to the free market as Randall Kennedy acknowledges that whites "were unable to control blacks simply with market pressures." Kennedy, Book Review, 98 YALE L.J. 521, 534 (1989). 


\section{CONCLUSION}

The traditional interpretation of the Plessy and Lochner decisions views them as two similarly reactionary, misdirected decisions from the same constitutional era. ${ }^{106}$ This Note has shown that such a conception is false. The classical American "civil rights" ideology, as expressed in Yick Wo, stood for judicial protection of both equal rights and economic freedom. Because of pervasive racism and sexism in American intellectual circles around turn of the century, equal rights were not protected in Plessy or Muller. Constitutional safeguards for economic freedom, however, survived into the Lochner era. This distinction was arbitrary; the Court's lack of support for equal rights led to state-imposed segregation and restrictions on women's labor; both tremendous impositions on economic liberty. Meanwhile, the Court's defense of economic liberty guaranteed economic opportunity to disadvantaged Blacks and immigrants. Indeed, had the Court applied the principles of economic freedom to segregation cases, the onerous laws would have been struck down. ${ }^{107}$

Today, legal ideology has come full circle, and equal rights appear to be well protected by the courts, while economic liberties, including occupational liberty, are generally ignored. ${ }^{108}$ While judicial protection from government discrimination has been a great victory for the individual rights of women and members of minority groups, the neglect of the other half of the classical view of civil rights, the protection of economic liberty, has had devastating consequences for disadvantaged individuals, especially Blacks. ${ }^{109}$ Organized labor and professional associations are still using governmental power to restrict economic opportunity by supporting restrictive legislation. As in Lochner and Adair, such legislation is not explicitly aimed at minority groups, but the laws disproportionately harm members of such groups nonetheless.

Many of the union abuses discussed earlier in this Note have been ameliorated by federal, state, and local civil rights laws, but Blacks are still vastly underrepresented in skilled trades due to artifical barriers imposed by crafts

106. See Hovenkamp, supra note 3, at 394-95 (discussing traditional criticisms of Plessy and Lochner); see also Bell, supra note 56. But see Epstein, supra note 18, at 753 ("Plessy championed big government because it worked for an assumption of government rectitude. Lochner stood for small (but not small enough) government.").

107. Cf. Epstein, supra note 18, at 751 ("under the standards for economic liberties developed shortly thereafter in Lochner, the statute in Plessy would have been doomed"). The Court soon did strike down one segregation law on economic liberty grounds. See Buchanan v. Warley, 245 U.S. 60 (1917) (striking down law forbidding purchase of residential property on block in which purchaser would not be in racial majority).

108. For more on the current status of the two halves of the traditional civil rights vision, including an argument that equality under the law is currently not well protected, see C. BOLICK, UNFINISHED BUSINESS: A CIVIL RIGHTS STRATEGY FOR AMERICA's THIRD CENTURY (1990); see also R. EPSTEN, TAKINGS (1985); B. SIEGAN, supra note 63; Epstein, Toward a Revitalization of the Contract Clause, 51 U. CHI. L. REV. 703 (1984); Karlin, supra note 62; Note, supra note 5 (federal courts have neglected their proper role as protectors of economic liberty from unconstitutional economic regulations).

109. See generally W. WILLIAMS, supra note 83 (restrictions on economic liberty disproportionately harm Blacks). 
unions and licensing laws. ${ }^{110}$ Occupational licensing exams generally, particularly those with written sections, discriminate against the poor, ${ }^{111}$ lesseducated, ${ }^{112}$ and, often, against members of minority groups in general. ${ }^{113}$ Other government-imposed barriers to economic opportunity include minimum wage laws, ${ }^{114}$ restrictions on taxicab ownership, ${ }^{115}$ bans on jitney services, ${ }^{116}$ the Davis-Bacon Act, ${ }^{117}$ restrictions on industrial homework, ${ }^{118}$ and various other forms of government regulation. ${ }^{119}$ As Professor Roback concludes: "[G]overnment ... must be restrained in order to allow disfavored minorities to make substantial economic progress."120 Until the classical civil rights vision is restored and economic liberty is once again protected, the equal rights of the disadvantaged will not be fully protected.

The Yick Wo decision represented an ephemeral victory for the classical civil rights vision. Unfortunately, only one half of that vision has ever been realized at one time. Today, one part of Yick Wo, the espousal of equal protection of the laws, is a legal reality, though still imperfectly administered. The other part of Yick Wo, the one espousing occupational liberty, is practically a dead letter, despite the fact that the protection of the individual's right to pursue

110. Id. at $94-95$.

111. Dorsey, The Occupational Licensing Queue, 15 J. HUM. RESOURCES 420, 425 (1980) (licensing exams test skills most practitioners will never need, and thus cause overinvestment in training, an expense many poor young people cannot afford).

112. Id. (Black potential beauticians in Missouri and Illinois failed written portions of licensing examination at a much higher rate than whites while doing as well as whites on practical section). Obviously, educational disparities between Blacks and whites, rather than any differences in "merit" were responsible for the gap in pass rates.

113. S. Michalik \& L. Trubek, Regulating Occupations: Legal Challenges to Licensing Examinations in Wisconsin (1988) (unpublished manuscript) (whites invariably had higher pass rates than Blacks, Hispanics, Native Americans, and Asians in twenty-six fields as diverse as real estate brokerage and nursing in Wisconsin); see also Demsetz, Minorities in the Marketplace, 43 N.C.L. REV. 271, 271 (1965); Wonnell, Economic Due Process and the Preservation of Competition, 11 HASTINGs CoNsT. L.Q. 91, 124 (1983) (barriers to occupational liberty are especially harmful to racial and ethric minorities).

114. See, e.g., Silverman, Equal Protection, Economic Legislation, and Racial Discrimination, 25 VAND. L. REV. 1183, 1191 (1972) ("[B]lacks, youths, and especially black youths[] are subjected disproportionately to the employment reduction effects of the minimum wage.").

115. W. WILLIAMS, supra note 83 , at $75-87$ (taxicab industry no longer performs traditional role of entry-level entrepreneurial opportunity because of government-imposed barriers to entry).

116. See, e.g., Newberry, Time for Jitneys, Houston Post, Mar. 30, 1987, at 2B, col. 1. For a history of the almost universal ban on urban jitney services, see Eckert \& Hilton, The Jitneys, 15 J.L. \& EcoN. 293, 307-25 (1972).

117. See, e.g., Barry, Congress's Deconstruction Theory, WASH. MONTHLY, Jan. 1990, at 10, 10 (DavisBacon Act prevents small, new construction companies, many owned by Blacks and women, from competing for federal contracts).

118. Homework, which is opposed by organized labor, allows women who wish to stay home with their children to do so while still participating in the labor force. Poorer women living in rural areas and immigrant women, legal and illegal, are the most common homeworkers. See Keller, Unions Battle Against Jobs in the Home, N.Y. Times, May 20, 1984, \$1, at 1, col. 1; see generally International Ladies' Garment Workers' Union v. Dole, 729 F. Supp. 877 (1989) (court allows Department of Labor to relax certain federal homework regulations over union opposition).

119. See generally P. Bearse, A Study of the Impact of State and Local Regulation On Small and Minority Businesses (July 4, 1988) (unpublished manuscript) (government regulation restricts economic mobility).

120. Roback, supra note 49 , at 1192. 
a lawful occupation free from unwarranted government interference is an important traditional American liberty, ${ }^{121}$ an important human right, ${ }^{122}$ and essential to the economic progress of the economically disadavantaged.

A recent federal district court case indicates that the courts might be becoming more sensitive to the importance of occupational liberty. Ego Brown, a Black resident of Washington, D.C., was a "shoeshine enterpeneur." He and the homeless men he employed were succeeding until the D.C. government, enforcing a 1905 law against outdoor bootblacks which probably had racist origins, closed them down. ${ }^{123}$ Brown sued and won. ${ }^{124}$ In response to a motion for a preliminary injunction, the judge wrote that "the federal courts' role in protecting American citizens from unreasonable economic regulation has been one of the hallmarks of American liberty, prosperity and progress."125

The idea of the interconnection between economic liberty and civil rights is making a comeback in intellectual circles as well. ${ }^{126}$ As Clint Bolick, Ego Brown's attorney, noted:

Civil rights and economic liberty are intertwined. . . . Throughout history in the United States and elsewhere, racial tolerance and individual freedom have developed most rapidly in practice and as an ideal in centers of free commerce. Conversely, the subjugation of some individuals by others has been most effectively accomplished where the power of the state has been exploited to deny or limit access to such commerce. ...

... [T] predecessors-commit itself to eliminating arbitrary economic regulations that deprive individuals of their civil right to pursue enterprises and engage in voluntary commerce. ${ }^{127}$

One can imagine that Mr. Yick Wo would surely agree.

121. Conant, Anti-Monopoly Tradition Under the Ninth and Fourteenth Amendments: Slaughter-house Cases Re-examined, 31 EMORY L.J. 786 (1982) (protection from government-sponsored monopoly is a traditional right under Anglo-American common law).

122. Cf. Levy, Property as a Human Right, 5 CONST. COMMENTARY 169, 183 (1988) ("With the exception of freedom of religion, nothing is more important than work and a chance at a career or a decent living.").

123. New Luster for Economic Liberty, INSIGHT, Apr. 10, 1989, at 18.

124. Brown v. Barry, 710 F. Supp. 352 (1989).

125. Motion for Preliminary Injunction, Brown v. Barry, No. 88-0565, slip op. 8 (D.D.C. Oct. 14, 1988); cf. Yick Wo v. Hopkins, 118 U.S. 356, 370 (1886) ("[T]he fundamental rights to life, liberty, and the pursuit of happiness ... . are secured by those maxims of constitutional law which are the monuments showing the victorious progress of the race in securing to men the blessings of civilization .....").

126. This intellectual trend has coincided with the growth in popularity of "classical liberalism" or "libertarianism," the modern versions of the radical liberalism of the 18th and 19th centuries. See generally" N. BARRY, ON CLASSICAL LIBERALISM AND LIBERTARIANISM (1987).

127. C. BoLICK, supra note 1 , at 94-95. 